Article

\title{
Yogurt Produced by Novel Natural Starter Cultures Improves Gut Epithelial Barrier In Vitro
}

\author{
Nikola Popović, Emilija Brdarić, Jelena Đokić, Miroslav Dinić, Katarina Veljović, Nataša Golić \\ and Amarela Terzić-Vidojević * \\ Institute of Molecular Genetics and Genetic Engineering, University of Belgrade, Vojvode Stepe 444a, \\ 11042 Belgrade, Serbia; popovicnikola@imgge.bg.ac.rs (N.P.); emilija@imgge.bg.ac.rs (E.B.); \\ jelena.djokic@imgge.bg.ac.rs (J.Đ.); mdinic@imgge.bg.ac.rs (M.D.); katarinav@imgge.bg.ac.rs (K.V.); \\ natasag@imgge.bg.ac.rs (N.G.) \\ * Correspondence: amarela@imgge.bg.ac.rs
}

Received: 4 September 2020; Accepted: 7 October 2020; Published: 15 October 2020

\begin{abstract}
Yogurt is a traditional fermented dairy product, prepared with starter cultures containing Streptococcus thermophilus and Lactobacillus bulgaricus that has gained widespread consumer acceptance as a healthy food. It is widely accepted that yogurt cultures have been recognized as probiotics, due to their beneficial effects on human health. In this study, we have characterized technological and health-promoting properties of autochthonous strains S. thermophilus BGKMJ1-36 and L. bulgaricus BGVLJ1-21 isolated from artisanal sour milk and yogurt, respectively, in order to be used as functional yogurt starter cultures. Both BGKMJ1-36 and BGVLJ1-21 strains have the ability to form curd after five hours at $42{ }^{\circ} \mathrm{C}$, hydrolyze $\alpha_{\mathrm{S} 1^{-}}, \beta-$, and $\mathrm{k}$ - casein, and to show antimicrobial activity toward Listeria monocytogenes. The strain BGKMJ1-36 produces exopolysaccharides important for rheological properties of the yogurt. The colonies of BGKMJ1-36 and BGVLJ1-21 strains that successfully survived transit of the yogurt through simulated gastrointestinal tract conditions have been tested for adhesion to intestinal epithelial Caco-2 cells. The results reveal that both strains adhere to Caco- 2 cells and significantly upregulate the expression of autophagy-, tight junction proteins-, and anti-microbial peptides-related genes. Hence, both strains may be interesting for use as a novel functional starter culture for production of added-value yogurt with health-promoting properties.
\end{abstract}

Keywords: Streptococcus thermophilus; Lactobacillus bulgaricus; yogurt; tight junctions; autophagy

\section{Introduction}

Yogurt is popular dairy product obtained by fermentation of lactose to lactic acid by lactic acid bacteria (LAB), and can be made from all types of milk [1,2]. As specified by Codex Alimentarius Standard No. 243/2003, "yogurt culture" is composed of Streptococcus thermophilus and Lactobacillus delbrueckii subsp. bulgaricus that are responsible for formation of typical yogurt flavor during sugar fermentation (glycolysis), proteins degradation (proteolysis), and fat degradation (lipolysis) [3]. They also produce exopolysaccharides (EPSs) that provide viscous texture of yogurt, and have a beneficial effect on the consumer's health [4]. In addition, as a dairy product, yogurt is an excellent source of vitamins, minerals, and calcium necessary for healthy teeth, bones, and immune system [5]. Besides the presence of $S$. thermophilus and L. bulgaricus in starter cultures, yogurt-like products may contain other LAB strains with functional probiotic properties [6]. The prerequisite for use of LAB strains in dairy starter cultures is their safety qualified presumption of safety (QPS) status recommended by the EFSA (2018) [7]. Moreover, starter cultures should be stable, and able to survive at refrigerator temperature during the storage period (usually 21-28 days). It was noticed that people who suffer from lactose intolerance can tolerate yogurt much better than milk, since yogurt cultures improve 
lactose digestion and eliminate symptoms of intolerance [8]. Hence, yogurt culture obtained the health claim from The Panel on Dietetic Products, EFSA for "lactose digestion", providing the health benefits to the host [9]. According to FAO-WHO (2002), "live microorganisms, which when administered in adequate amounts confer a health benefit on the host" are considered as probiotics [10]. FAO-WHO also defined that probiotics should be non-pathogenic, susceptible to clinically relevant antibiotics, should survive simulated gastrointestinal tract (GIT) conditions, and have the ability to colonize GIT epithelium of the host and to inhibit the growth of pathogenic and spoilage microorganisms [9,11-14]. In recent years, whole-genome sequence data has been increasingly used to identify potential probiotic strains, as well as to characterize strains in terms of their potential functional characteristics of importance $[7,15]$. Importantly, probiotics have a role in gut microbiota stabilization after various forms of diarrhea, or after prolonged use of antibiotics [16,17]. In line with that, daily consumption of yogurt containing an adequate amounts of live LAB can exert positive effects on gut microbiota [18]. Moreover, yogurts produced with probiotic LAB have shown an inhibitory effect on colon cancer, the ability to restore the gut homeostasis, preventing the development of various inflammatory bowel diseases, such as ulcerative colitis and Chron's disease, and mitigating the adverse effects of these diseases $[19,20]$. Indeed, the intestinal epithelium is shown to be the primary target for beneficial LAB. Recent data showed that LAB-associated biomolecules and metabolites could trigger autophagy [21-23], an important mechanism of cell recycling, required for anti-microbial protection, gut ecology regulation, appropriate intestinal immune response, and maintenance of epithelial barrier integrity [24]. Having in mind that all of these processes are regulated by autophagy, its modulation by LAB could represent a new strategy in maintenance of intestinal mucosal physiology.

Lactic acid bacteria are widespread in nature, but they are predominant in dairy products, especially those manufactured from raw milk. Indigenous microbiota of raw milk have a great impact on the specific sensory properties of raw milk products [25]. There is a recommendation to use starter culture in the production under aseptic condition in order to obtain high and constant quality of products for health consumers [9]. Many new LAB strains, so-called "wild strains", isolated from raw milk and raw milk products offer new opportunities for research and application in practice.

Considering the limited biodiversity of commercial starter cultures, there has been a trend of selection and development of new starter cultures from the autochthonous microbiota, isolated from artisanal spontaneous fermented food products and their use in industrial production of fermented foods. The use of such newly-isolated and well-characterized cultures aimed to produce fermented foods in a more controlled way, with similar sensory characteristics and nutritional value to the traditional products, even with special health-promoting properties [26-29].

In line with this, the aim of the present study was technological and probiotic characterization of $S$. thermophilus BGKMJ1-36 and L. bulgaricus BGVLJ1-21 strains isolated from raw milk artisanal sour milk and yogurt, respectively. We show that yogurt produced with these strains as a starter, at laboratory scale, possesses excellent probiotic properties, with the potential to modulate gut autophagy and strengthen the intestinal epithelial barrier.

\section{Materials and Methods}

2.1. Origin of Strains Streptococcus thermophilus BGKMJ1-36 and Lactobacillus bulgaricus BGVLJ1-21 and Growth Conditions

For this study, two thermophilic LAB strains from the bacterial collection of the Laboratory for Molecular Microbiology, Institute of Molecular Genetics and Genetic Engineering, University of Belgrade, Serbia were used. Streptococcus thermophilus BGKMJ1-36 was isolated from artisanal sour milk (traditionally manufactured in household in the village Jabuka, near the city Prijepolje, Serbia, altitude $1300 \mathrm{~m}$ ), while L. bulgaricus BGVLJ1-21 was isolated from artisanal yogurt (traditionally manufactured in household in the village Mlečiške Mehane, near the Vlasina Lake, Serbia, altitude $1307 \mathrm{~m}$ ) [29]. Both strains are deposited in the Belgian Coordinated Collections of Micro-organisms/Laboratorium voor Microbiologie - Bacteriënverzameling (BCCM/LMG), University of 
Ghent, Belgium under accession numbers LMG P-31742 for BGKMJ1-36 strain, and LMG P-28578 for BGVLJ1-21 strain.

The optimal growth of the strain BGKMJ1-36 is in M17 medium of pH 7.2 (Merck GmbH, Darmstadt, Germany), supplemented with $0.5 \%(w / v)$ glucose (GM17) at $37{ }^{\circ} \mathrm{C}$ under anaerobic conditions, while BGVLJ1-21 grows anaerobically in MRS medium of pH 5.7 (Merck). Anaerobic conditions were obtained in a $\mathrm{CO}_{2}$ incubator (HERAcell 150, Thermo Electron LED GmbH, Langenselbold, Germany) with $5 \% \mathrm{CO}_{2}$. BGKMJ1-36 and BGVLJ1-21 strains were stored at $-80{ }^{\circ} \mathrm{C}$ in GM17 and MRS broths supplemented with $15 \%(w / v)$ glycerol, respectively.

\subsection{Physiological, Biochemical, and Technological Characterization of Streptococcus thermophilus BGKMJ1-36 and Lactobacillus bulgaricus BGVLJ1-21 Strains}

The strains BGKMJ1-36 and BGVLJ1-21 were subjected to a set of biochemical and physiological tests as follows: growth at different temperatures $\left(15^{\circ} \mathrm{C}, 37^{\circ} \mathrm{C}\right.$, and $\left.45^{\circ} \mathrm{C}\right)$; growth in broth with $2 \% \mathrm{NaCl}(w / v) ; \mathrm{L}-a r g i n i n e ~ h y d r o l y s i s$, citrate utilization as energy source [30]; $\mathrm{CO}_{2}$ production from glucose in reconstituted MRS broth tubes containing inverted Durham bells; the production of acetoin by the Voges-Proskauer test [31]; and diacetyl production (qualitatively). After overnight incubation of the strains inoculated in $11 \%$ reconstituted skimmed milk (RSM) at $37^{\circ} \mathrm{C}, 1 \mathrm{~mL}$ of coagulated milk was mixed with $0.1 \mathrm{~g}$ of creatinine (Alfa Aesar, GmbH \& Co KG, Karlsuhe, Germany) and $1 \mathrm{~mL}$ of 30\% $\mathrm{NaOH}(w / v)$. Diacetyl production was scored as formation of a red halo at the top of the tubes after $2 \mathrm{~h}$ of incubation at room temperature. EPS production was detected visually (on GM17 or MRS agar plates, depending on the strain) as long strands when the colonies were extended with an inoculation loop [32]. Speed curdling was determined visually by time, measuring from the moment of inoculation of $11 \%$ sterile RSM with 3\% of each single starter culture grown up in RSM to the moment of curd forming at the incubation temperature of $42{ }^{\circ} \mathrm{C}$. Aggregation of tested starter cultures was detected visually after shaking of tubes with inoculated GM17 or MRS broth that were previously incubated overnight at $37^{\circ} \mathrm{C}$.

\subsection{Safety Assessment}

\subsubsection{Hemolytic and Gelatinase Activity Assays}

Hemolytic activity was determined on Columbia Blood Agar containing 5\% (v/v) defibrinated horse blood (Torlak, Belgrade, Serbia). After $48 \mathrm{~h}$ of incubation at $37^{\circ} \mathrm{C}$, hemolytic activities were detected as halo zones around the colony [33]. Gelatinase activity was determined on agar plates containing 3\% (w/v) gelatine (Difco, Becton Dickinson, Sparks, Meryland, USA). After $48 \mathrm{~h}$ of bacterial cultivation, plates were filled with $550 \mathrm{~g} / \mathrm{L}$ ammonium sulphate [34], and gelatinase activity was detected as halo zone. The absence of such zone was considered as absence of gelatinase activity. For both assays, the positive control was Enterococcus faecalis V583.

\subsubsection{Antibiotic Susceptibility Testing}

Minimal inhibitory concentrations (MICs) were determined by microdilution testing, following European Food Safety Authority criteria [7]. Susceptibility was tested against: ampicillin $(2 \mathrm{mg} / \mathrm{L})$, vancomycin $(4 \mathrm{mg} / \mathrm{L})$, gentamicin $(32 \mathrm{mg} / \mathrm{L})$, streptomycin $(64 \mathrm{mg} / \mathrm{L})$, erythromycin $(2 \mathrm{mg} / \mathrm{L})$, clindamycin $(2 \mathrm{mg} / \mathrm{L})$, tetracycline $(4 \mathrm{mg} / \mathrm{L})$, and chloramphenicol $(4 \mathrm{mg} / \mathrm{L})$ for S. thermophilus, while for L. bulgaricus, it was tested against ampicillin $(2 \mathrm{mg} / \mathrm{L})$, vancomycin $(2 \mathrm{mg} / \mathrm{L})$, gentamicin $(16 \mathrm{mg} / \mathrm{L})$, kanamycin $(16 \mathrm{mg} / \mathrm{L})$, streptomycin $(16 \mathrm{mg} / \mathrm{L})$, erythromycin $(1 \mathrm{mg} / \mathrm{L})$, clindamycin $(4 \mathrm{mg} / \mathrm{L})$, tetracycline $(4 \mathrm{mg} / \mathrm{L})$, and chloramphenicol $(4 \mathrm{mg} / \mathrm{L})$. Microdilution tests were performed in Hi-Sensitivity Test Broth (HiMedia, Mumbai, India). The final CFU per well was $5 \times 10^{6}$. Cell density was monitored after $24 \mathrm{~h}$ incubation at $37^{\circ} \mathrm{C}$ at $595 \mathrm{~nm}$ using spectrophotometer Plate Reader Infinite 200 pro (MTX Lab Systems, Vienna, Austria). En. faecalis V583 [35], S. thermophilus 
BGVLJ1-44, and Lactobacillus helveticus BGRA43 [36] were included as a quality control strains (control of antibiotic potency and quality of medium).

\subsection{Antimicrobial Activity}

The antimicrobial activity of S. thermophilus BGKMJ1-36 and L. bulgaricus BGVLJ1-21 was tested on various indicator strains: Lactobacillus plantarum A112, Lactobacillus casei BGHN14, Lactococcus lactis subsp. lactis BGMN1-596, Lactococcus lactis subsp. lactis BGZLM1-24, Lactococcus lactis subsp. cremoris NS1, Enterococcus faecalis BG221, Listeria monocytogenes ATCC 19111, Escherichia coli ATCC 25922, and Salmonella Enteritidis 654/7E by modified agar well diffusion assay [37]. Briefly, after incubation at $37^{\circ} \mathrm{C}$ for $16 \mathrm{~h}$, soft GM17 and MRS agars $(0.7 \%$ w/v) containing lactococci, enterococci, or lactobacilli indicator strains were overlaid onto respective GM17 and MRS plates. The plates were incubated overnight at $37^{\circ} \mathrm{C}$. A clear zone of inhibition of indicator strain growth around the well was taken as a positive signal for antimicrobial activity. A crystal of protease TYPE XIV (Sigma Chemie GmbH, Deisenhofen, Germany) was placed close to the edge of the well containing the overnight culture, to confirm the production of bacteriocin-like antimicrobial compounds of proteinaceous nature.

\subsection{Proteolytic Activity}

Both strains, BGKMJ1-36 and BGVLJ1-21, were assayed for proteolytic activity, as previously described [38]. The collected fresh cells (10 $\mathrm{mg}$ with an approximate density of $10^{10}$ cells/mL) were resuspended in $0.1 \mathrm{M}$ of sodium phosphate buffer $\left(1 \mathrm{M} \mathrm{NaH}_{2} \mathrm{PO}_{4}\right.$ and $\left.1 \mathrm{M} \mathrm{Na}_{2} \mathrm{HPO}_{4}\right)$ with $\mathrm{pH}$ of 6.8, and mixed in a 1:1 ratio with $5 \mathrm{mg} / \mathrm{mL}$ of $\alpha_{\mathrm{s} 1^{-}}, \beta-$, and $\mathrm{k}$ - casein, respectively (Sigma, St. Louis, MO, USA), dissolved in the identical buffer. The mixtures were incubated for $4 \mathrm{~h}$ at $42{ }^{\circ} \mathrm{C}$. The degradation of $\alpha_{\mathrm{s} 1}{ }^{-}, \beta-$, and $\mathrm{k}$ - casein was analyzed on $12.5 \%$ sodium dodecyl sulphate-polyacrylamide gel electrophoresis (SDS-PAGE).

\subsection{Yogurt Manufacturing}

Preparation of yogurt included milk fermentation process by use of defined starter cultures in the optimal ratios according to Dirar (1993) [39], with some modifications. Briefly, autoclaved RSM milk was inoculated with $2 \%$ of each overnight probiotic cultures grown in GM17 broth (BGKMJ1-36) and MRS broth (BGVLJ1-21), respectively. These single RSM milks inoculated with BGKMJ1-36 and BGVLJ1-21 strains were incubated overnight at $37^{\circ} \mathrm{C}$. Yogurt was prepared in pasteurized milk (Imlek, Belgrade, Serbia). Separately, BGKMJ1-36 and BGVLJ1-21 starter cultures were added in pasteurized milk, in an amount of $3 \%$ of the total milk amount in the ratio 1:2. The total amount of yogurt starter culture for milk inoculation was 3\% of total milk amount. The starter cultures were added in milk, separately, in optimal ratios: BGKMJ1-36:BGVLJ1-21 = 1:2. Incubation of inoculated milk was carried at $42{ }^{\circ} \mathrm{C}$ for 4 to $5 \mathrm{~h}$ until the $\mathrm{pH}$ value was lowered to about 4.8. After that, the glass bottles with fermented milk were rapidly cooled to $15^{\circ} \mathrm{C}$, and then shaken to obtain a homogenized and consistent structure of yogurt. Then, the cooling of the yogurt was continued in the refrigerator to $4{ }^{\circ} \mathrm{C}$, where the $\mathrm{pH}$ value of yogurt was further slowly lowered to 4.6 during cooling. The $\mathrm{pH}$ value and total viable count of yogurt bacteria was estimated immediately after inoculation of milk, as well as each hour during the first 4 to $5 \mathrm{~h}$ of the milk fermentation, and after 1, 7, 14, 21, and 28 days of storage of fermented milk at $4{ }^{\circ} \mathrm{C}$. The yogurt was previously aliquoted in separate batches, so that oxygen uptake was not possible during the storage. For each measurement of the $\mathrm{pH}$ value and the total number of viable bacteria, during the whole storage period, a separate batch was provided. Experiments were performed in three independent measurements.

\subsection{Survival in Simulated Gastrointestinal Tract Conditions}

Survival in chemically simulated GIT conditions was performed using an in vitro test, as described previously [40]. Viable cell counts were recovered from the one-day-old yogurt, after 90 min of gastric juice (125 mM NaCl, $7 \mathrm{mM} \mathrm{KCl}, 45 \mathrm{mM} \mathrm{NaHCO}, 0.3 \%$ pepsin (Sigma), pH 2) challenge, $10 \mathrm{~min}$ of 
duodenal juice (1\% bile salt (Sigma), $\mathrm{pH}$ 8) challenge, and $120 \mathrm{~min}$ of intestinal juice ( $0.3 \%$ bile salt, $0.1 \%$ pancreatin ("Pancreas acetone powder porcine Type I", Sigma), $\mathrm{pH} 8$ ) challenge, respectively. We used GM17 for BGKMJ1-36 and MRS for BGVLJ1-21 colony counts. Results were expressed as $\mathrm{CFU} / \mathrm{mL}$ of survived cells, and calculated from the viable counts recovered after every challenge of simulated GIT condition, with respect to the initial counts. Experiments were carried out in triplicate.

\subsection{Cell Culture and Treatments}

Differentiated human enterocyte-like Caco-2 cells were used as an in vitro small intestine epithelial barrier model. The cells were grown in Dulbecco's Modified Eagle Medium (DMEM) supplemented with $10 \%$ fetal bovine serum (FBS), $100 \mu \mathrm{g} / \mathrm{mL}$ streptomycin, $100 \mathrm{U} / \mathrm{mL}$ penicillin, and $2 \mathrm{mM} \mathrm{L}$-glutamine (Gibco). The cells were maintained in $75 \mathrm{~cm}^{2}$ flasks at $37^{\circ} \mathrm{C}$ in a humidified atmosphere containing $5 \%$ $\mathrm{CO}_{2}$. Caco-2 cells were seeded in a 24 -well plate $\left(2 \times 10^{5}\right.$ cells/well $)$, and incubated at $37^{\circ} \mathrm{C}$ for 21 days to allow differentiation (reaching the number of $2 \times 10^{6}$ of Caco- 2 cells/well). After the indicated time, the cells were treated for $2 \mathrm{~h}$ with $50 \mu \mathrm{L}$ of the product (containing $4.66 \times 10^{5}$ of live BGKMJ1-36, $4.5 \times 10^{5}$ of live BGVLJ1-21, and damaged bacterial particles) obtained by GIT treatment of $10^{8}$ live bacteria in yogurt (multiplicity of infection of 100). Before the treatment, GIT product was washed and resuspended in phosphate-buffered saline (PBS). After the treatment, cells were washed three times with PBS to remove the non-adherent bacteria, followed by a trypsinization step in order to detach cells (Trypsin-EDTA, Torlak) for the assessment of BGKMJ1-36 and BGVLJ1-21 adhesion properties [41]. Simultaneously, the cells were collected and stored at $-80^{\circ} \mathrm{C}$ for total RNA isolation and qPCR analysis.

\subsection{Cytotoxicity Assay}

A lactate dehydrogenase (LDH) Cytotoxicity Assay Kit (Thermo Fisher Scientific, Waltham, Massachusetts, USA) was used to evaluate the level of cytotoxicity of yogurt applied on Caco-2 cells. After two hours of treatments, supernatants were collected, and released LDH was detected by following the manufacturer's instructions. The absorbance was measured at $450 \mathrm{~nm}$ using the Plate Reader Infinite 200 pro (MTX Lab Systems).

\subsection{0. $R N A$ Isolation and $q P C R$}

Total RNA was extracted from Caco-2 cells according to the protocol described in [42]. All samples were treated with DNase I, using the Ambion DNA-free ${ }^{\mathrm{TM}}$ Kit (Thermo Fisher Scientific) to remove DNA contamination from RNA samples. Reversed transcription was done with the RevertAid RT kit, using 1 $\mu \mathrm{g}$ of isolated RNA as a template, according to the manufacturer's protocol (Thermo Fisher Scientific). Synthesized cDNA was amplified in a 7500 real-time PCR system (Applied Biosystems), using SYBR ${ }^{\mathrm{TM}}$ Green PCR Master Mix (Applied Biosystems) under the following conditions: $10 \mathrm{~min}$ at $95^{\circ} \mathrm{C}$ activation, 40 cycles of $15 \mathrm{~s}$ at $95^{\circ} \mathrm{C}$, and $60 \mathrm{~s}$ at $60^{\circ} \mathrm{C}$. Normalization was done against the GAPDH gene, using the $2^{-\Delta \Delta C t}$ method [43]. Primers were designed based on sequences available in the NCBI database by utilizing the NCBI Primer-Blast tool, available online (https://ncbi.nlm.nih.gov/tools/primer-blast). Primers and accession numbers of the genes used in the study are listed in Table 1. All primers were purchased from Thermo Fisher Scientific. 
Table 1. List of Primers Used in This Study.

\begin{tabular}{|c|c|c|c|}
\hline Gene Name & Accession Number of Gene & Primer Sequence $5^{\prime}-3^{\prime}$ & Reference \\
\hline AMBRA1_F & & GGTGGGAGGAGAGGGGATAG & \multirow{2}{*}{ This work } \\
\hline AMBRA1_R & NM_017749.3 & CGAGGGGCATGTCATCATTT & \\
\hline ULK1_F & & TTTTGTTTCTCCGTTGGGGC & \multirow{2}{*}{ This work } \\
\hline ULK1_R & NM_003565.4 & ACTCTTCCCGGGCTGCTAAT & \\
\hline UVRAG_F & & AGGAAGGAGTGCACTGCAAA & \multirow{2}{*}{ This work } \\
\hline UVRAG_R & NM_001386671.1 & AGGCAACTTGACACCGCATA & \\
\hline GABARAP_F & & CCCTCGTCCCGCTGATTTTA & \multirow{2}{*}{ This work } \\
\hline GABARAP_R & NM_007278.2 & ATCCСТCCAGCTTGTACCCA & \\
\hline PIK3C3_F & & GCTGTCCTGGAAGACCCAAT & \multirow{2}{*}{ This work } \\
\hline PIK3C3_R & NM_002647.4 & TTCTCACTGGCAAGGCCAAA & \\
\hline MAP1LC3B_F & & TTCAGGTTCACAAAACCCGC & \multirow{2}{*}{ This work } \\
\hline MAP1LC3B_R & NM_022818.5 & TCTCACACAGCCCGTTTACC & \\
\hline BECN1_F & & CTGGGACAACAAGTTTGACCAT & \multirow{2}{*}{ [44] } \\
\hline BECN1_R & & GCTCCTCAGAGTTAAACTGGGTT & \\
\hline ATG5_F & & CACAAGCAACTCTGGATGGGATTG & \multirow{2}{*}{ [45] } \\
\hline ATG5_R & & GCAGCCAC GGACGAAACAG & \\
\hline SQSTM1_F & & GCCAGAGGAACAGATGGAGT & \multirow{2}{*}{ [46] } \\
\hline SQSTM1_R & & TCCGATTCTG GCATCTGTAG & \\
\hline CLDN4_F & & ACAGACAAGCCTTACTCC & \multirow{2}{*}{ [21] } \\
\hline CLDN4_R & & GGAAGAACAAAGCAGAG & \\
\hline ZO-1_F & & AGGGGCAGTGGTGGTTTTCTGTTCTTTC & \multirow{2}{*}{ [47] } \\
\hline ZO-1_R & & GCAGAGGTCAAAGTTCAAGGCTCAAGAGG & \\
\hline OCLN_F & & TCAGGGAATATCCACCTATCACTTCAG & \multirow{2}{*}{ [21] } \\
\hline OCLN_R & & CATCAGCAGCAGCCATGTACTCTTCAC & \\
\hline CDH1_F & & AGCCTGTCGAAGCAGGATTG & \multirow{2}{*}{ This work } \\
\hline CDH1_R & NM_004360.5 & AGAAACAGCAAGAGCAGCAGA & \\
\hline DEFB1_F & & TGTCTGAGATGGCCTCAGGT & \multirow{2}{*}[48]{} \\
\hline DEFB1_R & & GGGCAGGCAGAATAGAGACA & \\
\hline GAPDH_F & & GTGAAGGTCGGAGTCAACG & \multirow{2}{*}{ [49] } \\
\hline GAPDH_R & & TGAGGTCAATGAAGGGGTC & \\
\hline IL-1 $\beta \_F$ & & TACGAATCTCCGACCACCACTACG & \multirow{2}{*}{ [50] } \\
\hline IL-1 $\beta \_R$ & & GTACAGGTGCATCGTGCACATAAGC & \\
\hline IL-6_F & & CACTCACCTCTTCAGAACGA & \multirow{2}{*}{ [51] } \\
\hline IL-6_R & & CTGTTCTGGAGGTACTCTAGG & \\
\hline TNF- $\alpha \_F$ & & AGCCCATGTTGTAGCAAACC & \multirow{2}{*}{ [52] } \\
\hline TNF- $\alpha \_R$ & & TGAGGTACAGGCCCTCTGAT & \\
\hline IL-8 F & & ACACAGAGCTGCAGAAATCAGG & \multirow{2}{*}{ [53] } \\
\hline IL-8 R & & GGCACAAACTTTCAGAGACAG & \\
\hline TGF- $\beta$ F & & CCGGGTTATGCTGGTTGTACAG & \multirow{2}{*}{ [54] } \\
\hline TGF- $\beta$ R & & AAGGACCTCGGCTGGAAGTGG & \\
\hline
\end{tabular}

\subsection{Statistical Analysis}

The results are presented as mean values \pm standard deviation (SD). The differences between groups were compared using Student's t-test. A p value less than 0.05 was considered statistically significant. The statistical analysis was performed, and graphs were prepared using GraphPad Prism 8 software (GraphPad Software, San Diego, CA, USA).

\section{Results and Discussion}

3.1. Characterization of Streptococcus thermophilus BGKMJ1-36 and Lactobacillus bulgaricus BGVLJ1-21 Strains

The interest of the dairy industry in production of fermented dairy products is the selection and use of LAB that converts lactose to lactic acid, degrades casein, and produces EPS and antimicrobial compounds, such as organic acids, hydrogen peroxide, antifungal peptides, and bacteriocins [55]. Considering this, we analyzed the physiological, biochemical, and technological characteristics of BGKMJ1-36 and BGVLJ1-21 strains. The results are summarized in Table 2. Both BGKMJ1-36 and BGVLJ1-21 strains have the ability to form curd after $5 \mathrm{~h}$ at $42^{\circ} \mathrm{C}$, hydrolyze $\alpha_{\mathrm{s} 1}-, \beta-$, and $\mathrm{k}$ - casein, and show antimicrobial activity towards the pathogenic strain Listeria monocytogenes ATCC19111. 
Proteolytic activity of yogurt cultures leads to the production of free amino acids, which may be converted to various flavor compounds, such as ammonia, amines, aldehydes, phenols, indole, and alcohols, all of them contributing to yogurt flavor [3]. LAB can produce various volatile compounds which contribute to the flavor formation of certain dairy products [56]. One of them is acetoin, produced by the BGKMJ1-36 strain. Acetoin is produced by LAB and various microorganisms which degrade glucose and other fermentable carbon sources via the Embden-Meyerhof pathway [57].

Table 2. Phenotypic, Biochemical, and Technological Characteristics of Streptococcus thermophilus BGKMJ1-36 and Lactobacillus bulgaricus BGVLJ1-21.

\begin{tabular}{|c|c|c|}
\hline Feature Tested & BGKMJ1-36 & BGVLJ1-21 \\
\hline Shape & Cocci in short and long chains & Longer rods, single and short chains \\
\hline Catalase test & - & - \\
\hline Gram staining & + & + \\
\hline Growth at $15^{\circ} \mathrm{C}$ in GM17 broth & - & - \\
\hline Growth at $37^{\circ} \mathrm{C}$ in GM17 broth & + & + \\
\hline Growth at $45^{\circ} \mathrm{C}$ in GM17 broth & + & + \\
\hline Growth in GM17 broth with $2 \% \mathrm{NaCl}$ & - & - \\
\hline Hydrolysis of arginine & - & - \\
\hline Citrate utilization & - & - \\
\hline Black zone on bile esculin agar & - & - \\
\hline Production of $\mathrm{CO}_{2}$ from glucose & - & - \\
\hline Acetoin production (VP) & + & - \\
\hline Diacetyl production & - & - \\
\hline Curd forming after & $4 \mathrm{~h}$ and $45 \mathrm{~min}$ & $5 \mathrm{~h}$ \\
\hline Exopolysaccharides production & + & - \\
\hline Aggregation ability & - & - \\
\hline$\alpha_{\mathrm{s} 1}$ casein & \pm & + \\
\hline \multirow{3}{*}{$\begin{array}{l}\text { lysis of } \quad \beta \text { casein } \\
\\
\text { K casein } \\
\text { Antimicrobial activity }\end{array}$} & + & + \\
\hline & \pm & + \\
\hline & $+{ }^{a}$ & $++^{a}$ \\
\hline
\end{tabular}

+ positive reaction; - negative reaction; \pm weak reaction. ${ }^{a}$ Both BGKMJ1-36 and BGVLJ1-21 strains inhibit the growth of Listeria monocytogenes ATCC19111, but antimicrobial compound is not of proteinaceous nature (Figure S1). Note: BGKMJ1-36 and BGVLJ1-21 strains are sensitive towards antibiotic suggested according to EFSA (2018).

These results are in accordance with the fact that $S$. thermophilus and L. bulgaricus are LAB widely used as starters in production of fermented dairy products, particularly in yogurts [58]. In addition to these technological properties, we showed that the BGKMJ1-36 strain is an excellent EPS producer (Table 2). The production of EPSs by starter cultures significantly contributes to rheological properties of dairy products, so the characterization of such LAB is of great interest for the dairy industry. Many $S$. thermophilus strains synthesize EPSs that contribute to the desirable viscous texture of fermented dairy products [59]. Production of EPSs could be modified by many factors, e.g., growth medium, temperature, $\mathrm{pH}$, fermentation time, and some other factors [60]. Interestingly, it was shown that $L$. bulgaricus was necessary to ensure better growth of some $S$. thermophilus strains in yogurt, as well as to induce their EPS production [61].

\subsection{Safety Assessment of Streptococcus thermophilus BGKMJ1-36 and Lactobacillus bulgaricus BGVLJ1-21 Strains}

After we showed that the mixed starter culture composed of BGKMJ1-36 BGVLJ1-21 strains have good technological properties, the hemolytic and gelatinase activities of the strains were investigated. No hemolytic activity was observed after $48 \mathrm{~h}$ of incubation for BGKMJ1-36, nor BGVLJ1-21. Additionally, both strains showed no gelatinase activity after $48 \mathrm{~h}$ of incubation on an agar plate filled with saturated ammonium sulphate solution. The absence of these properties is a favorable characteristic of new starters [62]. Although most dairy bacteria have a long history of use without significant established risk, the high prevalence of antibiotic resistance detected in commercial starter cultures strains raised the demand for novel starters susceptible to clinically relevant antibiotics $[63,64]$. 
Taking this into account, in this study, the susceptibility of these strains was tested on recommended concentrations of relevant antibiotics (EFSA, 2018). The results show that strains BGKMJ1-36 and BGVLJ1-21 are susceptible to the recommended minimal inhibitory concentrations (MIC) of all tested antibiotics (Table 3). The obtained results prove the safety status of these strains as starters for dairy production.

Table 3. Minimal Inhibitory Concentrations (MIC) of Nine Antibiotics on Streptococcus thermophilus BGKMJ1-36 and Lactobacillus bulgaricus BGVLJ1-21.

\begin{tabular}{ccc}
\hline Antibiotic & BGKMJ1-36 & BGVLJ1-21 \\
\hline Ampicillin & $\leq 1(2)$ & $\leq 1(2)$ \\
Vancomycin & $\leq 0.5(4)$ & $\leq 0.5(2)$ \\
Gentamicin & $\leq 16(32)$ & $\leq 8(16)$ \\
Kanamycin & n.r. & $\leq 4(16)$ \\
Streptomycin & $\leq 32(64)$ & $\leq 8(16)$ \\
Erythromycin & $\leq 1(2)$ & $\leq 0.5(1)$ \\
Clindamycin & $\leq 0.5(2)$ & $\leq 0.5(4)$ \\
Tetracycline & $\leq 2(4)$ & $\leq 0.5(4)$ \\
Chloramphenicol & $\leq 1(4)$ & $\leq 1(4)$
\end{tabular}

Breakpoints (mg/L) suggested by EFSA (2018) for Streptococcus thermophilus and Lactobacillus bulgaricus strains are reported in parentheses; note: n.r.: not required.

\subsection{Acidifying Kinetics of Streptococcus thermophilus BGKMJ1-36 and Lactobacillus bulgaricus BGVLJ1-21 Strains During Milk Fermentation and Yogurt Storage}

In addition to characterization of basic technological properties of BGKMJ1-36 and BGVLJ1-21 (Table 2), we further characterized their feature in co-culture in milk, during the laboratory-scale yogurt production. The rate of milk acidification by S. thermophilus and L. bulgaricus is a technological feature of major interest in yogurt production. For the yogurt production, pasteurized milk was inoculated with 3\% starter culture in BGKMJ1-36:BGVLJ1-21 = 1:2 ratio. Since both BGKMJ1-36 and BGVLJ1-21 strains were able to ferment milk individually, we also characterized the $\mathrm{pH}$ curve of each strain inoculated individually in milk. BGKMJ1-36 single culture decreased $\mathrm{pH}$ value faster ( $\mathrm{pH} 4.78$ for $4 \mathrm{~h}$ and $45 \mathrm{~min}$ ) than BGVLJ1-21 single culture ( $\mathrm{pH} 4.82$ after $5 \mathrm{~h}$ at $42{ }^{\circ} \mathrm{C}$ ), as well as in comparison to mixed starter culture ( $\mathrm{pH} 4.74$ after $5 \mathrm{~h}$ at $42^{\circ} \mathrm{C}$ ) (Figure $1 \mathrm{~A}$ ). On the other hand, the BGKMJ1-36 and mixed culture did not change $\mathrm{pH}$ value further, but BGVLJ1-21 single culture decreased the $\mathrm{pH}$ value to 4.64 during $24 \mathrm{~h}$. During cooling, the $\mathrm{pH}$ value of yogurt was slowly lowered to 4.61 after 7 days of storage at $4{ }^{\circ} \mathrm{C}$, while after 14 days of storage at $4^{\circ} \mathrm{C}$, pH value was 4.17, after 21 days, 4.13, and 4.01 after 28 days (Figure 1B). According to Gueimonde et al., post-acidification during storage depends on the LAB used for yogurt production, and greater increases of $\mathrm{pH}$ values were found in yogurts that included $L$. bulgaricus [65]. Our results are in accordance with these reports, confirming post-acidification and/or activity of residual microorganisms. In some cases, yogurts fermented with L. bulgaricus have been rated by consumers as being too acidic [66]. Hence, further tests at the industrial scale should include different ratios of BGKMJ1-36 and BGVLJ1-21 in order to decrease number of BGVLJ1-21 to avoid the post-acidification. 
A)

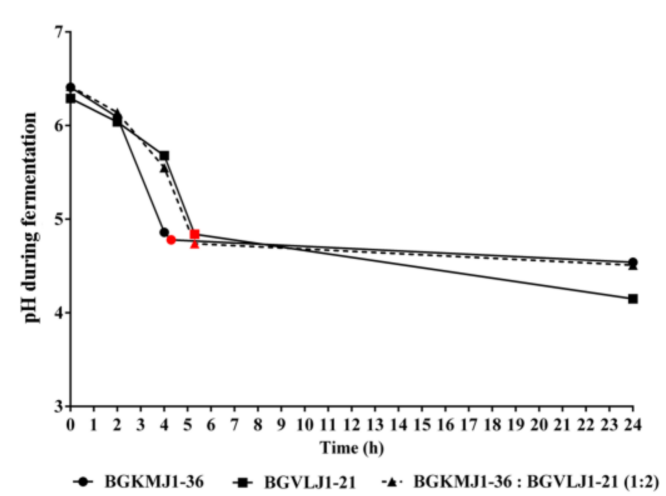

C)

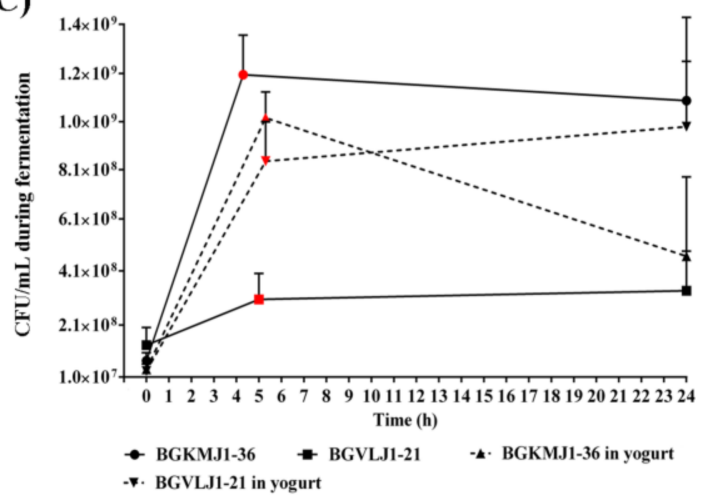

B)

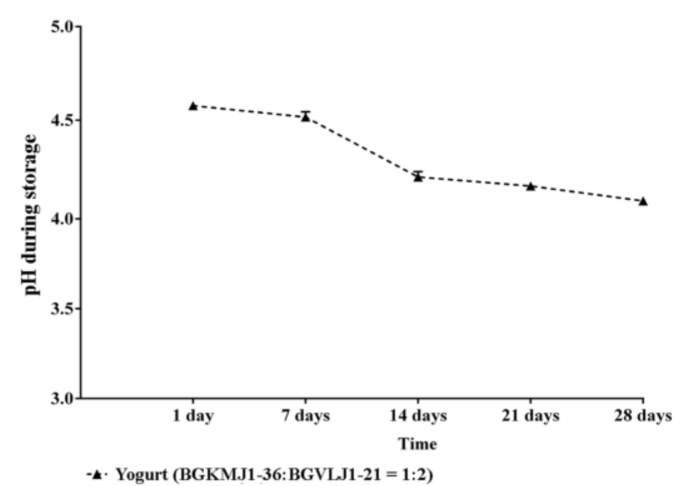

D)

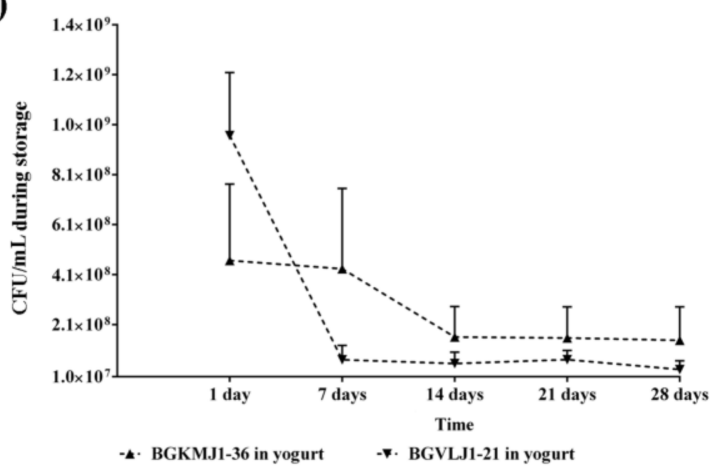

Figure 1. Acidification and growth dynamics of Streptococcus thermophilus BGKMJ1-36 and Lactobacillus bulgaricus BGVLJ1-21 strains during milk fermentation and storage. (A) Acidification curve of BGKMJ1-36 (circle), BGVLJ1-21 (square), and mix of BGKMJ1-36, and in ratio 1:2 (dashed line, triangle) during milk fermentation; (B) acidification curve of yogurt during storage at $4{ }^{\circ} \mathrm{C}$; (C) growth of BGKMJ1-36 (circle), BGVLJ1-21 (square), individually, as well as in mix in ratio of 1:2 ratio (dashed line, triangle) colony forming unit per milliliter $(\mathrm{CFU} / \mathrm{mL}$ ) during fermentation; (D) $\mathrm{CFU} / \mathrm{mL}$ during storage at $4{ }^{\circ} \mathrm{C}$. Note: circles, squares, and triangles colored in red represent the time of coagulation during milk fermentation.

3.4. Growth Kinetics of Streptococcus thermophilus BGKMJ1-36 and Lactobacillus bulgaricus BGVLJ1-21 Strains During Milk Fermentation and Storage

The growth kinetics of BGKMJ1-36 and BGVLJ1-21, in single and mixed cultures, during milk fermentation was evaluated. Species-specific bacterial counts were monitored over 28 days. The CFU of BGKMJ1-36 and BGVLJ1-21 (in single and mixed cultures) exponentially increased during the initial hours of fermentation, and reached a maximum around the fifth hour (Figure 1C: circles, squares, and triangles colored in red). Comparing the counts of bacteria when cultured individually and in combination, BGVLJ1-21 viable cell counts were higher in combination with BGKMJ1-36 $\left(8.3 \times 10^{8}\right.$ $\mathrm{CFU} / \mathrm{mL})$, in comparison to $\mathrm{CFU}$ when was individually inoculated $\left(3 \times 10^{8} \mathrm{CFU} / \mathrm{mL}\right)$. Moreover, the number of viable cells of BGVLJ1-21 in combination with BGKMJ1-36 increased during $24 \mathrm{~h}$ cooling time, suggesting that BGKMJ1-36 stimulates growth of BGVLJ1-21 (Figure 1C). In accordance with this, Ranadheer et al. noticed higher counts of viable L. bulgaricus, compared to $S$. thermophilus, in yogurt after co-incubation [67]. However, the viability of the BGKMJ1-36 strain decreased during $24 \mathrm{~h}$ cooling time. This observation could be explained by hydrogen peroxide production by L. bulgaricus, which could partially damage the $S$. thermophilus cells [68]. Also, the symbiotic relationship between S. thermophilus and L. bulgaricus was described, reflected in the fact that L. bulgaricus stimulates the growth of $S$. thermophilus when it is in the logarithmic phase of growth. After that, the large amount of lactic acid produced by L. bulgaricus inhibits the growth of S. thermophilus [6]. 
Noticeably, the viability of the BGVLJ1-21 started to decrease during the first week of storage. After this time, viable counts of BGVLJ1-21 $\left(1.5 \times 10^{7} \mathrm{CFU} / \mathrm{mL}\right)$ remained constant by the end of the 28 days (Figure 1D). The number of viable BGKMJ1-36 cells decreased significantly (37\%) during the second week, and remained constant during 28 days of storage (Figure 1D). These results represent the total counts of cultivable and undamaged cells grown on agar plates of GM17 for BGKMJ1-36 and MRS for BGVLJ1-21 after $24 \mathrm{~h}$ at $37^{\circ} \mathrm{C}$. Other authors reported similar results as ours, suggesting that the viability of bacteria depends on strain type, storage conditions, and culture mixture $[48,49,69,70]$.

\subsection{Effects of Simulated Gastrointestinal Tract Conditions on the Viability of Streptococcus thermophilus BGKMJ1-36 and Lactobacillus bulgaricus BGVLJ1-21 Strains in Yogurt}

One of the important features during the examination of starter cultures is the survival of unfavorable conditions in the GIT. The ability of BGKMJ1-36 and BGVLJ1-21 cells to survive in simulated GIT conditions was analyzed (Figure 2A). One-day-old yogurt contained $4.67 \times 10^{8} \mathrm{CFU} / \mathrm{mL}$ and $8.67 \times 10^{8} \mathrm{CFU} / \mathrm{mL}$ BGKMJ1-36 and BGVLJ1-21, respectively. After incubation for $90 \mathrm{~min}$ in gastric juice, the BGKMJ1-36 CFU decreased to $4.00 \times 10^{7} \mathrm{CFU} / \mathrm{mL}(8.6 \%)$, while CFU for BGVLJ1-21 was $5.00 \times 10^{7} \mathrm{CFU} / \mathrm{mL}$ (5.8\%). Results obtained by Soni et al. showed elimination of more than $73 \%$ of $L$. bulgaricus NCDC-253 and S. thermophilus NCDC-199 during an incubation period of $2 \mathrm{~h}$ at $\mathrm{pH} 2.0$ and 3.0. Comparing these data to our results, BGKMJ1-36 and BGVLJ1-21 had higher survival at low $\mathrm{pH}$ [71]. The additional decrease in the bacterial counts of both strains was observed after the 10-min incubation period in duodenal juice containing a high bile salt concentration $(1 \%), 1.47 \times 10^{7} \mathrm{CFU} / \mathrm{mL}$ (3.1\%) for BGKMJ1-36, and $3.67 \times 10^{7} \mathrm{CFU} / \mathrm{mL}(4.2 \%)$ for BGVLJ1-21. Finally, transfer and incubation for $2 \mathrm{~h}$ into intestinal juice $(0.3 \%$ of bile salt and $0.1 \%$ pancreatin) led to an additional decrease in the number of BGKMJ1-36 to $9.33 \times 10^{6} \mathrm{CFU} / \mathrm{mL}(2 \%)$ and BGVLJ1-21 to $2.05 \times 10^{6} \mathrm{CFU} / \mathrm{mL}(0.2 \%)$. Our results on the viability of BGKMJ1-36 and BGVLJ1-21 strains in the unfavorable GIT conditions are comparable with data available in the literature [72,73]. Many researchers have reported that low $\mathrm{pH}$ represents a crucial parameter in the viability of starter cultures [74,75]. It has been shown that milk has an impact as a protector of LAB in simulated GIT conditions and provides better survival [76]. Elizaquível et al. found that starter cultures in yogurt better survive the exposure to low $\mathrm{pH}$ and bile conditions, as well as digestive enzymes, than in media without carriers [77].

A)

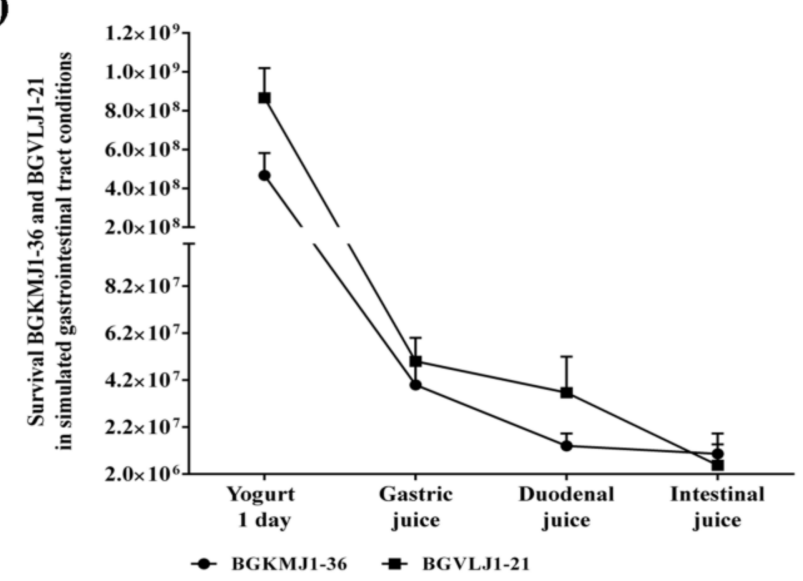

B)

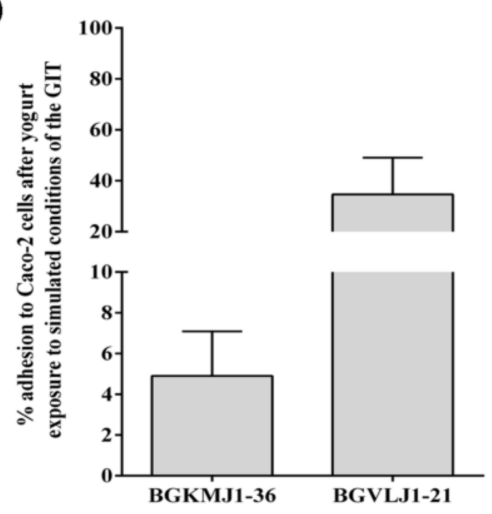

Figure 2. Survival of Streptococcus thermophilus BGKMJ1-36 and Lactobacillus bulgaricus BGVLJ1-21 in simulated gastrointestinal tract and adhesion to Caco-2 cells after exposure to last phase (intestinal juice) of simulated gastrointestinal tract conditions. (A) Survival of BGKMJ1-36 and BGVLJ1-21 in yogurt one-day-old after exposure to simulated gastrointestinal tract (GIT). Gastric juice $(\mathrm{pH}=2.0)$ contained pepsin $0.3 \%$, duodenal juice $(\mathrm{pH}=8.0)$ contained $1 \%$ bile salts, while intestinal juice $(\mathrm{pH}=$ 8.0) contained $0.3 \%$ bile salts and pancreatin $0.1 \%$; (B) adhesion of BGKMJ1-36 and BGVLJ1-21 from yogurt one-day-old after exposure to simulated gastrointestinal tract to Caco-2 cells. 
3.6. Adhesion of Streptococcus thermophilus BGKMJ1-36 and Lactobacillus bulgaricus BGVLJ1-21 Strains to Caco-2 Cells After Simulated Gastrointestinal Tract Conditions

Adhesion of LAB to epithelial cells mediates colonization of the GIT, and might be a requirement for the exclusion of pathogen and other beneficial effects on the host [78]. To analyze the adhesion ability of BGKMJ1-36 and BGVLJ1-21, the intestinal phase of yogurt digestion was added to Caco-2 cells. After $2 \mathrm{~h}$ incubation of intestinal phase of yogurt digestion on Caco- 2 cells, we found that about $5 \%$ of BGKMJ1-36 and 35\% of BGVLJ1-21 adheres to Caco-2 cells (Figure 2B). Interestingly, while Darilmaz et al. showed that the adhesion index for strains that produce EPSs was higher than in strains that do not produce EPSs [79], our previous results revealed that EPSs produced by Lactobacillus paraplantarum BGCG11 hindered its adhesion to intestinal epithelial cells [32], similarly to the results obtained in this study. Namely, the EPS-producing strain BGKMJ-36 adhered to Caco-2 cells with a lower affinity as the EPS-non-producing BGVLJ-21. Overall, both strains showed good binding abilities to Caco-2 cells, which could enable manifestation of their probiotic function. Results obtained by Fernández de Palencia et al. showed that L. bulgaricus LBY-27 and S. thermophilus STY-31 strains had relatively high levels of adhesion to Caco-2 cells of $9 \%$ and $5 \%$, respectively. Comparing these data to our results, BGKMJ1-36 had a similar adhesion ability, however, BGVLJ1-21 had higher adhesion ability to Caco-2 cells, and it was 35\% [80].

\subsection{Gene Expression Analysis Revealed the Upregulation of Autophagy and Epithelial Barrier Defense Markers}

Considering good adhesion properties of BGKMJ1-36 and BGVLJ1-21 to Caco-2 cells, we further analyzed the probiotic potential of these strains. Autophagy is a key process responsible for maintenance of intestinal physiology by controlling function of the various intestinal cells. Autophagy is important for preventing the invasion and dissemination of pathogens, maintaining barrier integrity, preserving intestinal homeostasis, and controlling mucosal inflammation [81]. Therefore, to investigate whether autophagy could be activated in Caco-2 cells upon BGKMJ1-36/BGVLJ1-21 yogurt treatment, we performed qPCR analysis of genes involved in different steps of the autophagy process, including autophagy induction (ULK1), autophagosome formation (AMBRA, BECN1, PIK3C3, UVRAG), autophagosome expansion (ATG5, GABARAP, MAP1LC3B), and retrieval of autophagic proteins (SQSTM1) [82,83]. For most of the autophagy-related genes, we detected significantly higher mRNA levels in yogurt-treated cells in comparison to untreated control (Figure 3A). This result emphasizes that bacteria present in yogurt exhibit the potential to activate autophagy in epithelial cells. These findings are comparable with results from our previous studies reporting that certain Lactobacillus strains exhibit the potential to trigger autophagy in different types of mammalian cells [22,23]. However, the application of strains and evaluation of their effects after the transit through simulated GIT have never been tested before. To exclude possibility that activation of autophagy is not a consequence of toxic effect of yogurt, which triggered autophagy, as cell death mechanism [84], we measured LDH release in the media from yogurt-treated cells. We did not notice differences in LDH levels between yogurt-treated cells and control (Figure 3B). This result implies that yogurt did not produce toxicity effect on Caco-2 cells, which is in accordance with strict probiotic regulations demanding that bacterial strains with QPS status should not be toxic or exhibit some deleterious effect on GIT epithelium of the host.

As autophagy has been linked with the improvement of tight junction barrier function in Caco-2 cells [85], we further analyzed epithelial barrier integrity by checking the expression of the most indicative tight junction markers. Tight junctions (TJs) form the border between the apical and basolateral cell surface responsible for maintenance of intestinal permeability [86]. The most prominent members among these proteins are claudins, ocludin, zonula occludens, and cadherins [87], which are encoded by the CLDN4, ZO-1, OCLN, and CDH1 genes, respectively. According to the gene expression analysis, we found that yogurt treatment significantly upregulated the expression of all abovementioned genes, suggesting that LAB present in yogurt exhibit the potential to strengthen these adhesion protein complexes (Figure 3C). TJs are often targeted by bacteria, leading to their disruption 
by pathogens, or increased synthesis in presence of probiotics and their metabolites $[21,88]$. Moreover, the upregulation of TJs correlates with the induction of autophagy, which is in accordance with the previous results pointing to a strong role of autophagy in controlling paracellular TJ permeability by targeting pore-forming tight junction protein claudin-2 [85].

A)

Autophagy

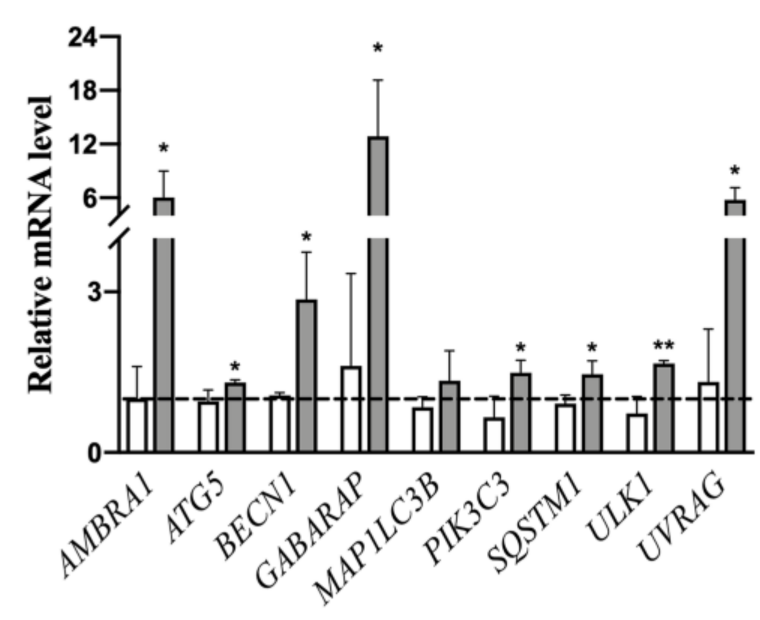

B)

Tigh junctions

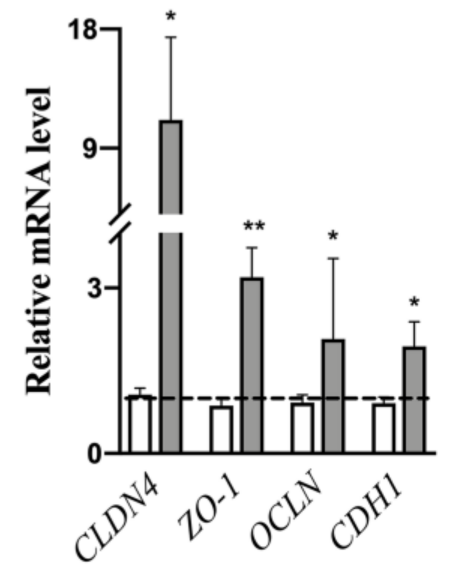

C)

Antimicrobial peptid

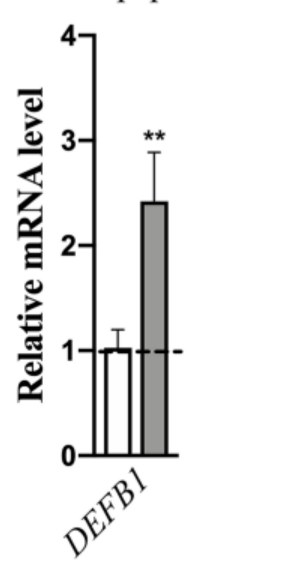

Control

Yogurt
D)

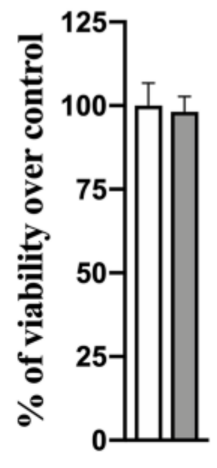

Figure 3. Yogurt application strengthens gut epithelial barrier. Expression of autophagy-related genes (A), tight-junction proteins genes (B), and human $\beta$ defensin (C) in Caco-2 cells treated with yogurt. Effect of yogurt on Caco-2 cells viability measured by lactate dehydrogenase (LDH) assay (D). Student's t-test was used to compare differences between groups $\left({ }^{*} p<0.05,{ }^{* *} p<0.01\right)$. Caco-2 cells treated with phosphate-buffered saline (PBS) were used as negative control.

Moreover, cytokine mediated changes in TJs expression and paracellular permeability, contributing to a different gut-related disorder. It has been showed that pro-inflammatory cytokines (TNF- $\alpha$, IL-1 $\beta$, IL-6, IL-8) increase intestinal epithelial tight junction permeability [89], while anti-inflammatory cytokines (TGF- $\beta$ ) [90] could restore function of disrupted barriers. Hence, we followed the expression levels of abovementioned cytokines, but we did not detect expression of pro-inflammatory cytokines ( $\mathrm{Ct}>35$ ) either in control or yogurt-treated cells, suggesting that yogurt did not cause inflammatory response. In the case of TGF- $\beta$, there was no difference in mRNA levels (data not shown), suggesting that upregulation of anti-inflammatory cytokine is not a mechanism which consequently leads to stimulation of TJs expression. 
Finally, the important probiotic feature of LAB is the potential to stimulate production of anti-microbial peptides (e.g., defensins), which play important roles in host defense [91]. We followed the expression levels of gene encoding human $\beta$-defensin distributed in the mucosal epithelium and skin, thus coming into direct contact with the external environment. Importantly, the results showed increased DEFB1 mRNA levels after yogurt treatment, compared to control (Figure 3D). Similar results were reported for Lactobacillus helveticus SBT2171 (LH2171) strain, which induced the expression of human $\beta$-defensin in Caco-2 cells by activating c-Jun N-terminal kinase (JNK) signaling via Toll-like receptor TLR2 [92].

\section{Conclusions}

Altogether, our findings pointed to the fact that yogurt prepared from novel autochthonous strains S. thermophilus BGKMJ1-36 and L. bulgaricus BGVLJ1-21 has a beneficial effect on the gut barrier by cross-linking the most important processes necessary for maintenance of epithelial homeostasis. To the best of our knowledge, this is the first study showing autophagy-inducing potential of LAB strains used for yogurt preparation. Also, in addition to lactic acid production by these strains, the induction of antimicrobial peptide production by host epithelial cells could be beneficial effects of this yogurt in the case of intestinal infection.

Taken together, these results support the further investigation of the beneficial effects of this mixed starter culture, in order to recommend it for use in the dairy industry as functional starter culture.

Supplementary Materials: The following are available online at http:/www.mdpi.com/2076-2607/8/10/ 1586/s1, Figure S1: Inhibitory zone result of the non-proteinaceous compound activity against Listeria monocytogenes ATCC19111.

Author Contributions: N.P. and A.T.-V.-conception and design of the study; N.P. and A.T.-V.-performed the main work; K.V. and A.T.-V.-participated in the research-physiological, biochemical, and technological characterization of new starter culture; N.P. and E.B.-participated in the research safety assessment; E.B., J.Đ., and M.D.- participated in the research-adhesion properties, isolation of RNA and qPCR; N.P., A.T.-V., M.D., and J.Đ.- - analyzed and interpreted results; N.P., A.T.-V., K.V., M.D., J.Đ., and N.G.—critically revised the data and prepared the manuscript for submission. All authors have read and agreed to the published version of the manuscript.

Funding: This work was funded by the Ministry of Education, Science and Technological Development of the Republic of Serbia, registration number: 451-03-68/2020-14/200042 agreement on the implementation and financing of research work in 2020.

Conflicts of Interest: The strains S. thermophilus BGKMJ1-36 and L. bulgaricus BGVLJ1-21 are deposited in the BCCM/LMG Bacterial Culture Collection, Belgium under patent deposition, and are subject of the license agreement between Institute of Molecular Genetics and Genetic Engineering, University of Belgrade, Serbia and Invetlab d.o.o. Adasevci, Serbia. The funders had no role in the design of the study; in the collection, analyses, or interpretation of data; in the writing of the manuscript, or in the decision to publish the results.

\section{References}

1. Shiby, V.K.; Mishra, H.N. Fermented milks and milk products as functional foods-A review. Crit. Rev. Food Sci. Nutr. 2013, 53, 482-496. [CrossRef] [PubMed]

2. Morelli, L. Yogurt, living cultures, and gut health. Am. J. Clin. Nutr. 2014, 99, 1248S-1250S. [CrossRef] [PubMed]

3. Chen, C.; Zhao, S.; Hao, G.; Yu, H.; Tian, H.; Zhao, G. Role of lactic acid bacteria on the yogurt flavour: A review. Int. J. Food Prop. 2017, 20, S316-S330. [CrossRef]

4. Ali, K.; Mehmood, M.H.; Iqbal, M.A.; Masud, T.; Qazalbash, M.; Saleem, S.; Ahmed, S.; Tariq, M.R.; Safdar, W.; Nasir, M.A.; et al. Isolation and characterization of exopolysaccharide-producing strains of Lactobacillus bulgaricus from curd. Food Sci. Nutr. 2019, 7, 1207-1213. [CrossRef] [PubMed]

5. El-Abbadi, N.H.; Dao, M.C.; Meydani, S.N. Yogurt: Role in healthy and active aging. Am. J. Clin. Nutr. 2014, 99, 1263S-1270S. [CrossRef] [PubMed]

6. Aryana, K.J.; Olson, D.W. A 100-Year Review: Yogurt and other cultured dairy products. J. Dairy Sci. 2017, 100, 9987-10013. [CrossRef] [PubMed] 
7. Rychen, G.; Aquilina, G.; Azimonti, G.; Bampidis, V.; Bastos, M.d.L.; Bories, G.; Chesson, A.; Cocconcelli, P.S.; Flachowsky, G.; Gropp, J.; et al. Guidance on the characterisation of microorganisms used as feed additives or as production organisms. EFSA J. 2018, 16, e05206. [CrossRef] [PubMed]

8. Saborido, R.; Leis, R. [Yogurt and dietary recommendations for lactose intolerance]. Nutr. Hosp. 2018, 35, 45-48. [CrossRef] [PubMed]

9. Araya, M.; Gopal, P.; Lindgren, S.E.; Lodi, R.; Oliver, G.; Saxelin, M.L.; Severin, A.L.; Stanton, C. Probiotics in Food: Health and Nutritional Properties and Guidelines for Evaluation, Food and Agriculture Organization of the United Nations; World Health Organization: Rome, Italy, 2006; pp. 2-3. ISBN 978-92-5-105513-7.

10. EFSA Panel on Dietetic Products, Nutrition and Allergies (NDA). Scientific Opinion on the substantiation of health claims related to live yoghurt cultures and improved lactose digestion (ID 1143, 2976) pursuant to Article 13(1) of Regulation (EC) No 1924/2006. EFSA J. 2010, 8, 1763. [CrossRef]

11. Bintsis, T. Lactic acid bacteria as starter cultures: An update in their metabolism and genetics. AIMS Microbiol. 2018, 4, 665-684. [CrossRef]

12. Iravani, S.; Korbekandi, H.; Mirmohammadi, S.V. Technology and potential applications of probiotic encapsulation in fermented milk products. J. Food Sci. Technol. 2015, 52, 4679-4696. [CrossRef] [PubMed]

13. Kok, C.R.; Hutkins, R. Yogurt and other fermented foods as sources of health-promoting bacteria. Nutr. Rev. 2018, 76, 4-15. [CrossRef] [PubMed]

14. Hatti-Kaul, R.; Chen, L.; Dishisha, T.; Enshasy, H.E. Lactic acid bacteria: From starter cultures to producers of chemicals. FEMS Microbiol. Lett. 2018, 365. [CrossRef]

15. Reid, G.; Gadir, A.A.; Dhir, R. Probiotics: Reiterating What They Are and What They Are Not. Front. Microbiol. 2019, 10. [CrossRef] [PubMed]

16. Khalid, K. An overview of lactic acid bacteria. Int. J. Biosci. (IJB) 2011, 1, 1-13.

17. Guarino, A.; Guandalini, S.; Lo Vecchio, A. Probiotics for Prevention and Treatment of Diarrhea. J. Clin. Gastroenterol. 2015, 49 (Suppl. 1), S37-S45. [CrossRef]

18. Lisko, D.J.; Johnston, G.P.; Johnston, C.G. Effects of Dietary Yogurt on the Healthy Human Gastrointestinal (GI) Microbiome. Microorganisms 2017, 5. [CrossRef]

19. Wilkins, T.; Sequoia, J. Probiotics for Gastrointestinal Conditions: A Summary of the Evidence. Am. Fam. Physician 2017, 96, 170-178.

20. Yoon, H.; Park, Y.S.; Lee, D.H.; Seo, J.-G.; Shin, C.M.; Kim, N. Effect of administering a multi-species probiotic mixture on the changes in fecal microbiota and symptoms of irritable bowel syndrome: A randomized, double-blind, placebo-controlled trial. J. Clin. Biochem. Nutr. 2015, 57, 129-134. [CrossRef]

21. Sokovic Bajic, S.; Djokic, J.; Dinic, M.; Veljovic, K.; Golic, N.; Mihajlovic, S.; Tolinacki, M. GABA-Producing Natural Dairy Isolate From Artisanal Zlatar Cheese Attenuates Gut Inflammation and Strengthens Gut Epithelial Barrier in vitro. Front. Microbiol. 2019, 10, 527. [CrossRef]

22. Bajić, S.S.; Đokić, J.; Dinić, M.; Tomić, S.; Popović, N.; Brdarić, E.; Golić, N.; Tolinački, M. GABA potentiate the immunoregulatory effects of Lactobacillus brevis BGZLS10-17 via ATG5-dependent autophagy in vitro. Sci. Rep. 2020, 10, 1347. [CrossRef] [PubMed]

23. Dinić, M.; Lukić, J.; Djokić, J.; Milenković, M.; Strahinić, I.; Golić, N.; Begović, J. Lactobacillus fermentum Postbiotic-induced Autophagy as Potential Approach for Treatment of Acetaminophen Hepatotoxicity. Front. Microbiol. 2017, 8, 594. [CrossRef] [PubMed]

24. Larabi, A.; Barnich, N.; Nguyen, H.T.T. New insights into the interplay between autophagy, gut microbiota and inflammatory responses in IBD. Autophagy 2020, 16, 38-51. [CrossRef] [PubMed]

25. Bluma, A.; Ciprovica, I.; Sabovics, M. The influence of non-starter lactic acid bacteria on swiss-type cheese quality. Agric. Food 2017, 5, 34-41.

26. Hansen, E.B. Commercial bacterial starter cultures for fermented foods of the future. Int. J. Food Microbiol. 2002, 78, 119-131. [CrossRef]

27. Johansen, E. Use of Natural Selection and Evolution to Develop New Starter Cultures for Fermented Foods. Annu. Rev. Food Sci. Technol. 2018, 9, 411-428. [CrossRef] [PubMed]

28. Bintsis, T. Lactic acid bacteria: Their applications in foods. J. Bacteriol. Mycol. 2018, 6, 89-94. [CrossRef]

29. Terzić-Vidojević, A.; Veljović, K.; Tolinački, M.; Živković, M.; Lukić, J.; Lozo, J.; Fira, Đ.; Jovčić, B.; Strahinić, I.; Begović, J.; et al. Diversity of non-starter lactic acid bacteria in autochthonous dairy products from Western Balkan Countries - Technological and probiotic properties. Food Res. Int. 2020, 136, 109494. [CrossRef] [PubMed] 
30. Kempler, G.M.; McKay, L.L. Biochemistry and Genetics of Citrate Utilization in Streptococcus lactis ssp. diacetylactis. J. Dairy Sci. 1981, 64, 1527-1539. [CrossRef]

31. Zourari, A.; Roger, S.; Chabanet, C.; Desmazeaud, M. Caractérisation de bactéries lactiques thermophiles isolées de yaourts artisanaux grecs. I. Souches de Streptococcus salivarius subsp thermophilus. Le Lait 1991, 71, 445-461. [CrossRef]

32. Nikolic, M.; López, P.; Strahinic, I.; Suárez, A.; Kojic, M.; Fernández-García, M.; Topisirovic, L.; Golic, N.; Ruas-Madiedo, P. Characterisation of the exopolysaccharide (EPS)-producing Lactobacillus paraplantarum BGCG11 and its non-EPS producing derivative strains as potential probiotics. Int. J. Food Microbiol. 2012, 158, 155-162. [CrossRef] [PubMed]

33. Valenzuela, A.S.; Omar, N.B.; Abriouel, H.; López, R.L.; Veljovic, K.; Cañamero, M.M.; Topisirovic, M.K.L.; Gálvez, A. Virulence factors, antibiotic resistance, and bacteriocins in enterococci from artisan foods of animal origin. Food Control. 2009, 20, 381-385. [CrossRef]

34. Lopes, M.d.F.S.; Simões, A.P.; Tenreiro, R.; Marques, J.J.F.; Crespo, M.T.B. Activity and expression of a virulence factor, gelatinase, in dairy enterococci. Int. J. Food Microbiol. 2006, 112, 208-214. [CrossRef] [PubMed]

35. Hürlimann, L.M.; Corradi, V.; Hohl, M.; Bloemberg, G.V.; Tieleman, D.P.; Seeger, M.A. The Heterodimeric ABC Transporter EfrCD Mediates Multidrug Efflux in Enterococcus faecalis. Antimicrob. Agents Chemother. 2016, 60, 5400-5411. [CrossRef] [PubMed]

36. Golić, N.; Veljović, K.; Popović, N.; Djokić, J.; Strahinić, I.; Mrvaljević, I.; Terzić-Vidojević, A. In vitro and in vivo antagonistic activity of new probiotic culture against Clostridium difficile and Clostridium perfringens. BMC Microbiol. 2017, 17. [CrossRef]

37. Tagg, J.R.; McGiven, A.R. Assay System for Bacteriocins. Appl. Microbiol. 1971, 21, 943. [CrossRef]

38. Kojic, M.; Fira, D.; Banina, A.; Topisirovic, L. Characterization of the Cell Wall-Bound Proteinase of Lactobacillus casei HN14. Appl. Environ. Microbiol. 1991, 57, 1753-1757. [CrossRef]

39. Dirar, H.A. The Indigenous Fermented Foods of the Sudan: A Study in African Food and Nutrition; CAB International Publishing: Wallingford, UK, 1993; ISBN 978-0-85198-858-0.

40. Sánchez, B.; Fernández-García, M.; Margolles, A.; de los Reyes-Gavilán, C.G.; Ruas-Madiedo, P. Technological and probiotic selection criteria of a bile-adapted Bifidobacterium animalis subsp. lactis strain. Int. Dairy J. 2010, 20, 800-805. [CrossRef]

41. Živković, M.; Miljković, M.S.; Ruas-Madiedo, P.; Markelić, M.B.; Veljović, K.; Tolinački, M.; Soković, S.; Korać, A.; Golić, N. EPS-SJ Exopolisaccharide Produced by the Strain Lactobacillus paracasei subsp. paracasei BGSJ2-8 Is Involved in Adhesion to Epithelial Intestinal Cells and Decrease on E. coli Association to Caco-2 Cells. Front. Microbiol. 2016, 7, 286. [CrossRef]

42. Lukic, J.; Strahinic, I.; Milenkovic, M.; Golic, N.; Kojic, M.; Topisirovic, L.; Begovic, J. Interaction of Lactobacillus fermentum BGHI14 with rat colonic mucosa: Implications for colitis induction. Appl. Environ. Microbiol. 2013, 79, 5735-5744. [CrossRef]

43. Livak, K.J.; Schmittgen, T.D. Analysis of Relative Gene Expression Data Using Real-Time Quantitative PCR and the 2- $\Delta \Delta \mathrm{CT}$ Method. Methods 2001, 25, 402-408. [CrossRef] [PubMed]

44. Liu, K.; Shi, Y.; Guo, X.; Wang, S.; Ouyang, Y.; Hao, M.; Liu, D.; Qiao, L.; Li, N.; Zheng, J.; et al. CHOP mediates ASPP2-induced autophagic apoptosis in hepatoma cells by releasing Beclin-1 from Bcl-2 and inducing nuclear translocation of Bcl-2. Cell Death Dis. 2014, 5, e1323. [CrossRef]

45. He, Z.; Liu, H.; Agostini, M.; Yousefi, S.; Perren, A.; Tschan, M.P.; Mak, T.W.; Melino, G.; Simon, H.U. p73 regulates autophagy and hepatocellular lipid metabolism through a transcriptional activation of the ATG5 gene. Cell Death Differ. 2013, 20, 1415-1424. [CrossRef]

46. Sahani, M.H.; Itakura, E.; Mizushima, N. Expression of the autophagy substrate SQSTM1/p62 is restored during prolonged starvation depending on transcriptional upregulation and autophagy-derived amino acids. Autophagy 2014, 10, 431-441. [CrossRef]

47. Elamin, E.; Jonkers, D.; Juuti-Uusitalo, K.; van IJzendoorn, S.; Troost, F.; Duimel, H.; Broers, J.; Verheyen, F.; Dekker, J.; Masclee, A. Effects of Ethanol and Acetaldehyde on Tight Junction Integrity: In Vitro Study in a Three Dimensional Intestinal Epithelial Cell Culture Model. PLoS ONE 2012, 7. [CrossRef]

48. Martin, H.; McGhie, T.K.; Bentley-Hewitt, K.; Christeller, J. PPAR $\gamma$ as a sensor of lipase activity and a target for the lipase inhibitor orlistat. Lipids Health Dis. 2013, 12, 48. [CrossRef] 
49. Freudenberger, T.; Deenen, R.; Kretschmer, I.; Zimmermann, A.; Seiler, L.F.; Mayer, P.; Heim, H.-K.; Köhrer, K.; Fischer, J.W. Synthetic gestagens exert differential effects on arterial thrombosis and aortic gene expression in ovariectomized apolipoprotein E-deficient mice. Br. J. Pharmacol. 2014, 171, 5032-5048. [CrossRef] [PubMed]

50. Laquerriere, P.; Grandjean-Laquerriere, A.; Addadi-Rebbah, S.; Jallot, E.; Laurent-Maquin, D.; Frayssinet, P.; Guenounou, M. MMP-2, MMP-9 and their inhibitors TIMP-2 and TIMP-1 production by human monocytes in vitro in the presence of different forms of hydroxyapatite particles. Biomaterials 2004, 25, 2515-2524. [CrossRef]

51. Xie, J.; Wu, X.; Zhou, Q.; Yang, Y.; Tian, Y.; Huang, C.; Meng, X.; Li, J. PICK1 confers anti-inflammatory effects in acute liver injury via suppressing M1 macrophage polarization. Biochimie 2016, 127, 121-132. [CrossRef] [PubMed]

52. Kouser, L.; Paudyal, B.; Kaur, A.; Stenbeck, G.; Jones, L.A.; Abozaid, S.M.; Stover, C.M.; Flahaut, E.; Sim, R.B.; Kishore, U. Human Properdin Opsonizes Nanoparticles and Triggers a Potent Pro-inflammatory Response by Macrophages without Involving Complement Activation. Front. Immunol. 2018, 9, 131. [CrossRef] [PubMed]

53. Angrisano, T.; Pero, R.; Peluso, S.; Keller, S.; Sacchetti, S.; Bruni, C.B.; Chiariotti, L.; Lembo, F. LPS-induced IL-8 activation in human intestinal epithelial cells is accompanied by specific histone $\mathrm{H} 3$ acetylation and methylation changes. BMC Microbiol. 2010, 10, 172. [CrossRef] [PubMed]

54. Dragicevic, S.; Milosevic, K.; Nestorovic, B.; Nikolic, A. Influence of the Polymorphism C-509T in the TGFB1 Gene Promoter on the Response to Montelukast. Pediatric Allergy Immunol. Pulmonol. 2017, 30, $239-245$. [CrossRef]

55. Egan, K.; Field, D.; Rea, M.C.; Ross, R.P.; Hill, C.; Cotter, P.D. Bacteriocins: Novel Solutions to Age Old Spore-Related Problems? Front. Microbiol. 2016, 7, 461. [CrossRef] [PubMed]

56. Cuffia, F.; Bergamini, C.V.; Wolf, I.V.; Hynes, E.R.; Perotti, M.C. Characterization of volatile compounds produced by Lactobacillus helveticus strains in a hard cheese model. Food Sci. Technol. Int. 2018, 24, 67-77. [CrossRef] [PubMed]

57. Xiao, Z.; Xu, P. Acetoin metabolism in bacteria. Crit. Rev. Microbiol. 2007, 33, 127-140. [CrossRef]

58. Hols, P.; Hancy, F.; Fontaine, L.; Grossiord, B.; Prozzi, D.; Leblond-Bourget, N.; Decaris, B.; Bolotin, A.; Delorme, C.; Dusko Ehrlich, S.; et al. New insights in the molecular biology and physiology of Streptococcus thermophilus revealed by comparative genomics. FEMS Microbiol. Rev. 2005, 29, 435-463. [CrossRef]

59. Zhang, T.; Zhang, C.; Li, S.; Zhang, Y.; Yang, Z. Growth and exopolysaccharide production by Streptococcus thermophilus ST1 in skim milk. Braz. J. Microbiol. 2011, 42, 1470-1478. [CrossRef]

60. Vaningelgem, F.; Zamfir, M.; Adriany, T.; De Vuyst, L. Fermentation conditions affecting the bacterial growth and exopolysaccharide production by Streptococcus thermophilus ST 111 in milk-based medium. J. Appl. Microbiol. 2004, 97, 1257-1273. [CrossRef]

61. Nordmark, E.-L.; Yang, Z.; Huttunen, E.; Widmalm, G. Structural studies of an exopolysaccharide produced by Streptococcus thermophilus THS. Biomacromolecules 2005, 6, 105-108. [CrossRef] [PubMed]

62. Marty, E.; Bodenmann, C.; Buchs, J.; Hadorn, R.; Eugster-Meier, E.; Lacroix, C.; Meile, L. Prevalence of antibiotic resistance in coagulase-negative staphylococci from spontaneously fermented meat products and safety assessment for new starters. Int. J. Food Microbiol. 2012, 159, 74-83. [CrossRef]

63. Kastner, S.; Perreten, V.; Bleuler, H.; Hugenschmidt, G.; Lacroix, C.; Meile, L. Antibiotic susceptibility patterns and resistance genes of starter cultures and probiotic bacteria used in food. Syst. Appl. Microbiol. 2006, 29, 145-155. [CrossRef] [PubMed]

64. Chamba, J.F.; Jamet, E. Contribution to the safety assessment of technological microflora found in fermented dairy products. Int. J. Food Microbiol. 2008, 126, 263-266. [CrossRef] [PubMed]

65. Gueimonde, M.; Delgado, S.; Mayo, B.; Ruas-Madiedo, P.; Margolles, A.; de los Reyes-Gavilán, C.G. Viability and diversity of probiotic Lactobacillus and Bifidobacterium populations included in commercial fermented milks. Food Res. Int. 2004, 37, 839-850. [CrossRef]

66. Saarela, M.; Mogensen, G.; Fondén, R.; Mättö, J.; Mattila-Sandholm, T. Probiotic bacteria: Safety, functional and technological properties. J. Biotechnol. 2000, 84, 197-215. [CrossRef]

67. Senaka Ranadheera, C.; Evans, C.A.; Adams, M.C.; Baines, S.K. Probiotic viability and physico-chemical and sensory properties of plain and stirred fruit yogurts made from goat's milk. Food Chem. 2012, 135, 1411-1418. [CrossRef]

68. Dave, R.I.; Shah, N.P. Viability of yoghurt and probiotic bacteria in yoghurts made from commercial starter cultures. Int. Dairy J. 1997, 7, 31-41. [CrossRef] 
69. Gilliland, S.E.; Reilly, S.S.; Kim, G.B.; Kim, H.S. Viability during storage of selected probiotic lactobacilli and bifidobacteria in a yogurt-like product. J. Food Sci. 2002, 67, 3091-3095. [CrossRef]

70. Riazi, A.; Ziar, H. Growth and viability of yogurt starter organisms in honey-sweetened skimmed milk. Afr. J. Biotechnol. 2008, 7, 2055-2063.

71. Soni, R.; Jain, N.K.; Shah, V.; Soni, J.; Suthar, D.N.; Gohel, P. Development of probiotic yogurt: Effect of strain combination on nutritional, rheological, organoleptic and probiotic properties. J. Food Sci. Technol. 2020, 57, 2038-2050. [CrossRef]

72. Fernández, M.F.; Boris, S.; Barbés, C. Probiotic properties of human lactobacilli strains to be used in the gastrointestinal tract. J. Appl. Microbiol. 2003, 94, 449-455. [CrossRef]

73. Tarrah, A.; da Silva Duarte, V.; de Castilhos, J.; Pakroo, S.; Lemos Junior, W.J.F.; Luchese, R.H.; Fioravante Guerra, A.; Rossi, R.C.; Righetto Ziegler, D.; Corich, V.; et al. Probiotic potential and biofilm inhibitory activity of Lactobacillus casei group strains isolated from infant feces. J. Funct. Foods 2019, 54, 489-497. [CrossRef]

74. Sánchez, A.H.; Rejano, L.; Montaño, A.; de Castro, A. Utilization at high pH of starter cultures of lactobacilli for Spanish-style green olive fermentation. Int. J. Food Microbiol. 2001, 67, 115-122. [CrossRef]

75. Aziz, K.; Haseeb Zaidi, A.; Fatima, H.N.; Tariq, M. Lactobacillus fermentum strains of dairy-product origin adhere to mucin and survive digestive juices. J. Med. Microbiol. 2019, 68, 1771-1786. [CrossRef] [PubMed]

76. Martinez, R.C.R.; Aynaou, A.-E.; Albrecht, S.; Schols, H.A.; De Martinis, E.C.P.; Zoetendal, E.G.; Venema, K.; Saad, S.M.I.; Smidt, H. In vitro evaluation of gastrointestinal survival of Lactobacillus amylovorus DSM 16698 alone and combined with galactooligosaccharides, milk and/or Bifidobacterium animalis subsp. lactis Bb-12. Int. J. Food Microbiol. 2011, 149, 152-158. [CrossRef] [PubMed]

77. Elizaquível, P.; Sánchez, G.; Salvador, A.; Fiszman, S.; Dueñas, M.T.; López, P.; Fernández de Palencia, P.; Aznar, R. Evaluation of yogurt and various beverages as carriers of lactic acid bacteria producing 2-branched (1,3)- $\beta$-D-glucan. J. Dairy Sci. 2011, 94, 3271-3278. [CrossRef] [PubMed]

78. Dimitrov, Z.; Gotova, I.; Chorbadjiyska, E. In vitro characterization of the adhesive factors of selected probiotics to Caco-2 epithelium cell line. Biotechnol. Biotechnol. Equip. 2014, 28, 1079-1083. [CrossRef] [PubMed]

79. Darilmaz, D.O.; Aslım, B.; Suludere, Z.; Akca, G. Influence of gastrointestinal system conditions on adhesion of exopolysaccharide-producing Lactobacillus delbrueckii subsp. bulgaricus strains to caco-2 cells. Braz. Arch. Biol. Technol. 2011, 54, 917-926. [CrossRef]

80. Fernández de Palencia, P.; López, P.; Corbí, A.L.; Peláez, C.; Requena, T. Probiotic strains: Survival under simulated gastrointestinal conditions, in vitro adhesion to Caco-2 cells and effect on cytokine secretion. Eur. Food Res. Technol. 2008, 227, 1475-1484. [CrossRef]

81. Haq, S.; Grondin, J.; Banskota, S.; Khan, W.I. Autophagy: Roles in intestinal mucosal homeostasis and inflammation. J. Biomed. Sci. 2019, 26, 19. [CrossRef]

82. Mizushima, N. Autophagy: Process and function. Genes Dev. 2007, 21, 2861-2873. [CrossRef]

83. Yin, Z.; Pascual, C.; Klionsky, D.J. Autophagy: Machinery and regulation. Microb. Cell 2016, 3, 588-596. [CrossRef] [PubMed]

84. Wang, H.; Cheng, X.; Zhang, L.; Xu, S.; Zhang, Q.; Lu, R. A surface-layer protein from Lactobacillus acidophilus NCFM induces autophagic death in HCT116 cells requiring ROS-mediated modulation of mTOR and JNK signaling pathways. Food Funct. 2019, 10, 4102-4112. [CrossRef] [PubMed]

85. Nighot, P.K.; Hu, C.-A.A.; Ma, T.Y. Autophagy enhances intestinal epithelial tight junction barrier function by targeting claudin-2 protein degradation. J. Biol. Chem. 2015, 290, 7234-7246. [CrossRef] [PubMed]

86. Zihni, C.; Mills, C.; Matter, K.; Balda, M.S. Tight junctions: From simple barriers to multifunctional molecular gates. Nat. Rev. Mol. Cell Biol. 2016, 17, 564-580. [CrossRef]

87. Jiang, Y.; Guo, C.; Zhang, D.; Zhang, J.; Wang, X.; Geng, C. The altered tight junctions: An important gateway of bacterial translocation in cachexia patients with advanced gastric cancer. J. Interferon Cytokine Res. 2014, 34, 518-525. [CrossRef]

88. Popović, N.; Djokić, J.; Brdarić, E.; Dinić, M.; Terzić-Vidojević, A.; Golić, N.; Veljović, K. The Influence of Heat-Killed Enterococcus faecium BGPAS1-3 on the Tight Junction Protein Expression and Immune Function in Differentiated Caco-2 Cells Infected With Listeria monocytogenes ATCC 19111. Front. Microbiol. 2019, 10, 412. [CrossRef]

89. Capaldo, C.T.; Nusrat, A. Cytokine regulation of tight junctions. Biochim. Biophys. Acta 2009, 1788, 864-871. [CrossRef] 
90. Howe, K.L.; Reardon, C.; Wang, A.; Nazli, A.; McKay, D.M. Transforming Growth Factor- $\beta$ Regulation of Epithelial Tight Junction Proteins Enhances Barrier Function and Blocks Enterohemorrhagic Escherichia coli O157:H7-Induced Increased Permeability. Am. J. Pathol. 2005, 167, 1587-1597. [CrossRef]

91. Ganz, T. Defensins: Antimicrobial peptides of innate immunity. Nat. Rev. Immunol. 2003, 3, 710-720. [CrossRef]

92. Kobatake, E.; Kabuki, T. S-Layer Protein of Lactobacillus helveticus SBT2171 Promotes Human $\beta$-Defensin 2 Expression via TLR2-JNK Signaling. Front. Microbiol. 2019, 10, 2414. [CrossRef]

Publisher's Note: MDPI stays neutral with regard to jurisdictional claims in published maps and institutional affiliations.

(C) 2020 by the authors. Licensee MDPI, Basel, Switzerland. This article is an open access article distributed under the terms and conditions of the Creative Commons Attribution (CC BY) license (http://creativecommons.org/licenses/by/4.0/). 